\title{
Colectomy with Diversion
}

National Cancer Institute

\section{Source}

National Cancer Institute. Colectomy with Diversion. NCI Thesaurus. Code C135732.

Surgical diversion of the gastrointestinal tract performed in conjunction with a colectomy. 